\title{
World Gas Prospects: Which Role for the Middle East?*
}

\author{
M.-F. Chabrelie ${ }^{1}$ \\ 1 Cedigaz, 1 et 4, avenue de Bois-Préau, 92852 Rueil-Malmaison Cedex - France \\ e-mail: m-francoise.chabrelie@ifp.fr \\ * Presented at the 11th SPE Middle East Oil Show \& Conference Round Table "Gas today and into the future"
}

\begin{abstract}
Résumé - Perspectives mondiales du gaz naturel : quel rôle pourrait jouer le Moyen-Orient ? Les politiques de diversification énergétique mises en œuvre dans les pays industrialisés et dans de nombreux pays en voie de développement depuis le début des années 1970 ont permis au gaz naturel d'accroître régulièrement sa présence dans le bilan énergétique mondial. Ainsi, au cours des vingt dernières années, le gaz naturel a enregistré le taux de croissance le plus élevé parmi les énergies fossiles, et sa part de marché est progressivement passée de 18,9\% en 1975 à $23 \%$ en 1997.

Aujourd'hui, des facteurs d'ordres économiques et environnementaux font du gaz naturel l'énergie de choix sur de nombreux marchés. Le gaz jouit en effet d'un certain nombre d'atouts (réserves importantes, flexibilité, utilisations performantes) qui lui confèrent une place majeure dans tous les scénarios de prévision de demande énergétique. Le développement le plus spectaculaire se fera sans conteste dans le secteur électrique.

Doté de réserves gazières considérables, le Moyen-Orient représentera une source d'approvisionnement essentielle pour bon nombre de pays industrialisés et plusieurs projets d'exportation de gaz par méthaniers ou par gazoducs sont déjà à l'étude. Par ailleurs, au cours des dix dernières années, la contribution du gaz naturel dans le bilan énergétique a augmenté de façon significative dans la plupart des pays du MoyenOrient. La croissance de l'utilisation du gaz devrait se poursuivre à un rythme soutenu, en particulier sous l'influence du secteur électrique, de la pétrochimie et de l'autoconsommation de l'industrie pétrolière. Ces perspectives prometteuses de demande de gaz sur la plupart des marchés de la région pourraient conduire au développement d'un réseau de transport intrarégional. Toutefois, bien que des opportunités existent, elles ne doivent pas masquer les nombreux défis que cette région devra relever pour contribuer plus largement au bilan gazier mondial dans les années à venir.
\end{abstract}

Mots-clés : demande de gaz, réserves, marchés régionaux, Moyen-Orient, exportations, GNL, projets de gazoducs, défis.

\begin{abstract}
World Gas Prospects: Which Role for the Middle East? - Since the early 1970s, the policies of energy diversification that have been implemented in the industrialized countries and in many developing countries have enabled natural gas to regularly increase its role in the world energy balance. Thus, during the past twenty years, natural gas recorded the highest growth rate among fossil fuels, and its share in the energy market has gradually risen from 18.9\% in 1975 to 23\% in 1997.

Today, thanks to favorable economic and environmental factors, natural gas has become the fuel of choice on many markets. Indeed, gas is blessed with a certain number of favorable assets (abundant reserves, flexibility, high-performance uses) which give it a major role in all energy demand forecast scenarios. The most spectacular development will indisputably take place in the power generation sector.
\end{abstract}


Endowed with a considerable gas potential, the Middle East will represent an essential source of supply for many industrialized countries and several gas export projects, either by LNG tanker or by pipelines are currently being contemplated. During the past decade, the contribution of natural gas to the energy mix also grew substantially in most Middle Eastern countries. The increase in gas demand should continue at a sustained rate, mainly driven by the power generation sector, petrochemicals and energy consumption by the hydrocarbons industry. These promising prospects for gas demand in most of the markets in the region might lead to the development of an intra-regional network. However, although opportunities exist, the region will have to meet many challenges in order to contribute more largely to the world gas balance in the years to come.

Keywords: gas demand, reserves, regional markets, Middle East, exports, $L N G$, pipeline projects, challenges.

\section{INTRODUCTION}

Over the past decades, natural gas has been taking an increasing importance in meeting energy requirements worldwide. Today, this energy source is emerging as the fuel of the next century. Indeed, natural gas is a clean and efficient fuel, and these assets will undoubtedly lead to a significant increase in its share of the world energy balance. The efficiency of gas technologies, to which the use of natural gas is directly related (electricity generation), and an increasing awareness of ecological problems, put natural gas in a privileged position when future energy balances are concerned.

Despite a number of drastic changes currently taking place on the international gas scene, long-term demand forecasts are bright. They show sustained annual growth rates of around 2.5 to $3 \%$ between now and 2015 . At this date, demand for gas should be in the region of $3700 \cdot 10^{9} \mathrm{~m}^{3}$ (Fig. 1), contributing to more than $25 \%$ of world primary energy demand, compared to $23 \%$ in 1997 and $17 \%$ only in 1970 .

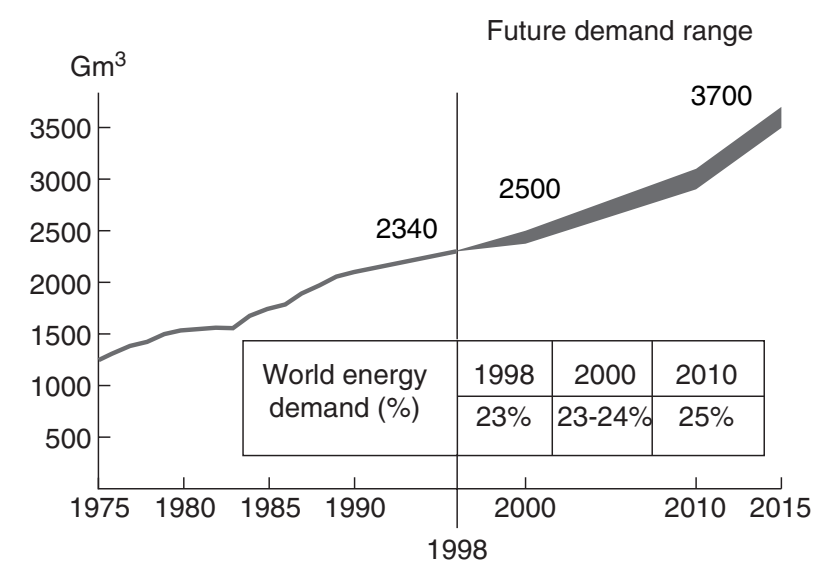

Figure 1

Outlook for world gas demand.
The combined effects of several favorable parameters, either technical, environmental or political offer natural gas substantial prospects for growth.

\section{FAVORABLE FACTORS DRIVING FUTURE GAS DEMAND}

\subsection{Natural Gas Emerges as an Abundant Source of Energy}

The worldwide steady gas exploration success achieved over the past few decades has led to a continuous upward revision of proved gas reserves. As a result, a feeling of confidence in a relative abundance of resources has developed progressively, leading the United States and Europe in particular to abrogate their laws initially banning gas use in power plants. It has also to be reminded that up to the mid- 80 s, the utilities were relatively disinclined to use gas due to the potential risks affecting supplies. These fears have gradually evaporated for various reasons.

With $152000 \cdot 10^{9} \mathrm{~m}^{3}$ proved gas reserves now stand at a level approaching (98.3\%) that of oil reserves, compared to an estimated $50 \%$ in 1970 . The world ratio of reserves to production is about 60 years, compared to 40 years for oil. Figure 2 illustrates the distribution of proved gas reserves worldwide.

Similarly, ultimate resources have been revised upward significantly during the past few years, now estimated to range from 400 to $500 \cdot 10^{12} \mathrm{~m}^{3}$. These figures demonstrate that the gas potential is immense and that very large gas reserves still remain to be discovered.

Technological advances in producing new and more difficult resources also reinforced the confidence in gas. These achievements resulted from the 1986 oil aftershock which forced oil producers to reduce oil production costs. The gas industry benefited from these advances particularly for offshore production with the use of lighter floating platforms and subsea production facilities as shown on Figure 3. A good example of this technological approach is given by the development of the Troll Field in Norway. 


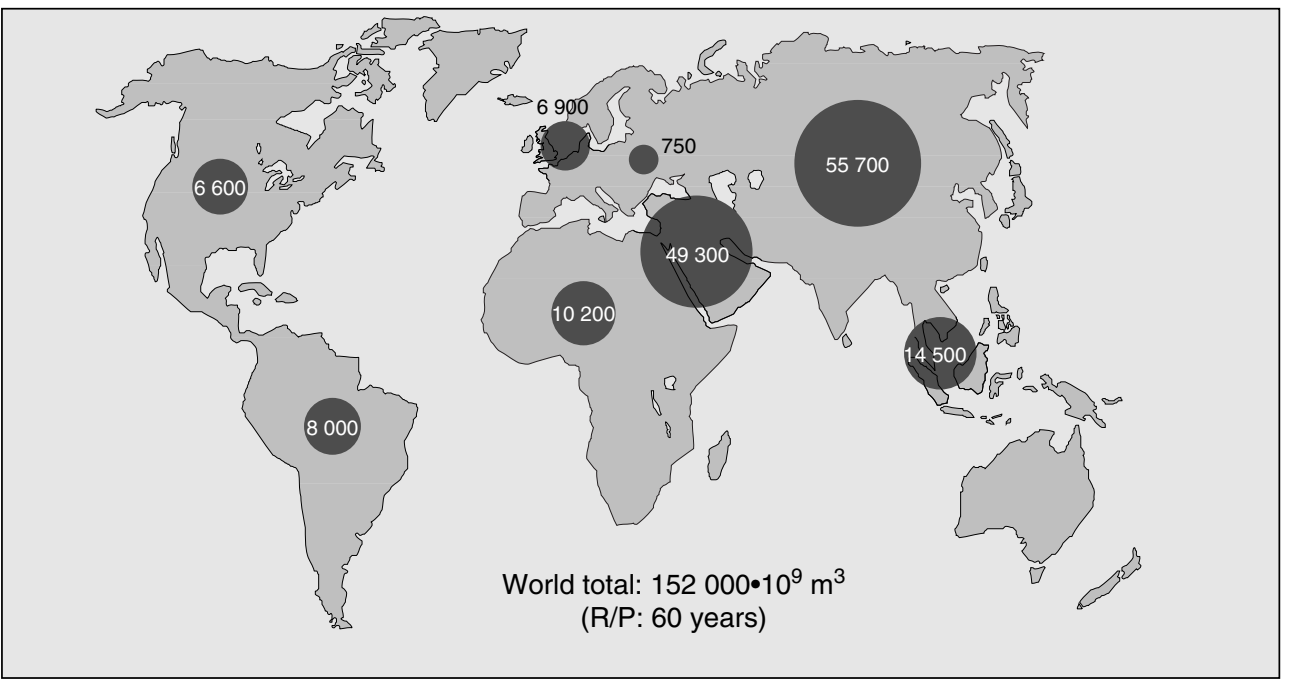

Figure 2

Proved natural gas reserves in the world - 1 January, 1998.

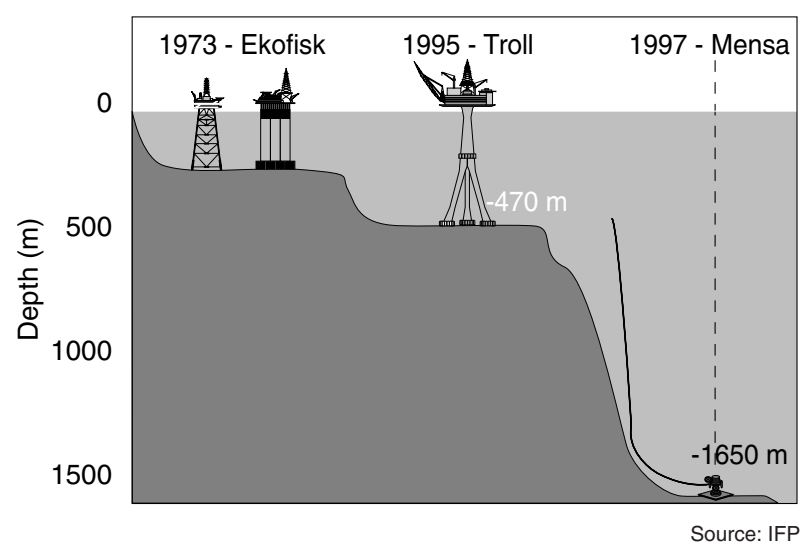

Figure 3

Evolution of offshore gas production systems.

Shell, the operator, announced a $\$ 0.7$ billion reduction in costs, as the result of extensive design optimisation which has substantially reduced platform weight. As a consequence of these innovations, the average cost of production in the North Sea has dropped from $\$ 3.7 / \mathrm{MBtu}$ in the 1980s to about $\$ 2 /$ MBtu today. Offshore gas production now amounts to $550 \cdot 10^{9} \mathrm{~m}^{3} / \mathrm{y}$ or $24 \%$ of the world total production, compared with only $12 \%$ in 1970 .

The evolution in the political context also opens new trade prospects. The emergence of fifteen republics resulting from the breakup of the USSR revealed the considerable oil and gas potential around the Caspian Sea. Although political issues still remain to be solved, the European and Asian markets are within reach of this gas.

\subsection{Environment Issues}

Environment protection and a growing awareness of ecological problems favor the gas option. The chemical nature of natural gas is the main reason for its wide acceptance as the cleanest of fossil fuels. Increasing gas use will help reducing greenhouse gases effects and coping with the problem of acid rains.

The quantity of $\mathrm{CO}_{2}$ released by the combustion of fossil fuels results from their carbon content. Natural gas contains less carbon and more hydrogen than the other fossil fuels. Owing to its physical and chemical properties, natural gas is the energy source that releases the least $\mathrm{CO}_{2}$ for the same amount of electricity produced: about $67 \%$ less than coal and $50 \%$ less than petroleum products due to efficiencies.

In addition, natural gas contains no particles, and its sulphur and heavy metals content is infinitesimal. Its combustion only produces negligible fractions of $\mathrm{SO}_{2}$ and low $\mathrm{NO}_{\mathrm{x}}$ emissions in comparison with fuel oil and coal. In boilers, as a rule, natural gas emits 1.5 to 2 times less $\mathrm{NO}_{\mathrm{x}}$ than fuel oil, and 2.5 times less than coal. $\mathrm{SO}_{2}$ emissions released by gas combustion are about $90 \%$ lower compared with those produced by coal. 


\subsection{Increasing Gas Use in Power Generation}

The use of natural gas is directly linked to the performances of gas technologies. New technologies applied to cogeneration and combined-cycles now provide better efficiencies, lower production costs and plant investments, flexibility of use, thus offering gas a determinant advantage in power generation. In particular, gas-fired combined-cycle power plants offer efficiencies in the range of 55\%, far higher to those obtained with conventional gas turbines, now enabling gas to be competitive for base-load operation.

Power generation is the fastest-growing sector for gas, accounting for about $50 \%$ of the expected worldwide demand growth by 2010 . At this date, power generation might account for 35 to $37 \%$ of total gas consumption, ahead of the residential/commercial sector (29\%) and at a level approaching that of the industrial sector (33\%). The largest growth rates in demand for gas in power generation will be registered in Asia, Latin America, the Middle East, North America and Western Europe (Spain, Turkey, Portugal).

\subsection{Transformations in the World Gas Industry}

The deregulation of the gas industry certainly represents the main trend that shapes the world gas industry today. In the United States and in the United Kingdom where the process is now complete, the reorganisation of the activities has led to the emergence of gas-to-gas competition and to the introduction of a spot price for gas. Such changes can considerably influence the future organisation of the markets.

\section{REGIONAL GAS MARKETS: TRADITIONAL AND EMERGING}

Since they had adequate gas resources, a market and financial means, the $O E C D$ countries and the CIS largely introduced gas in their energy balances. In 1998, these two regions accounted for $70 \%$ of world consumption, including $30 \%$ for North America, 24\% for the CIS and 17\% for Western Europe (Fig. 4). The other regions which initiated the development of their markets more recently only account for $30 \%$ of world consumption.

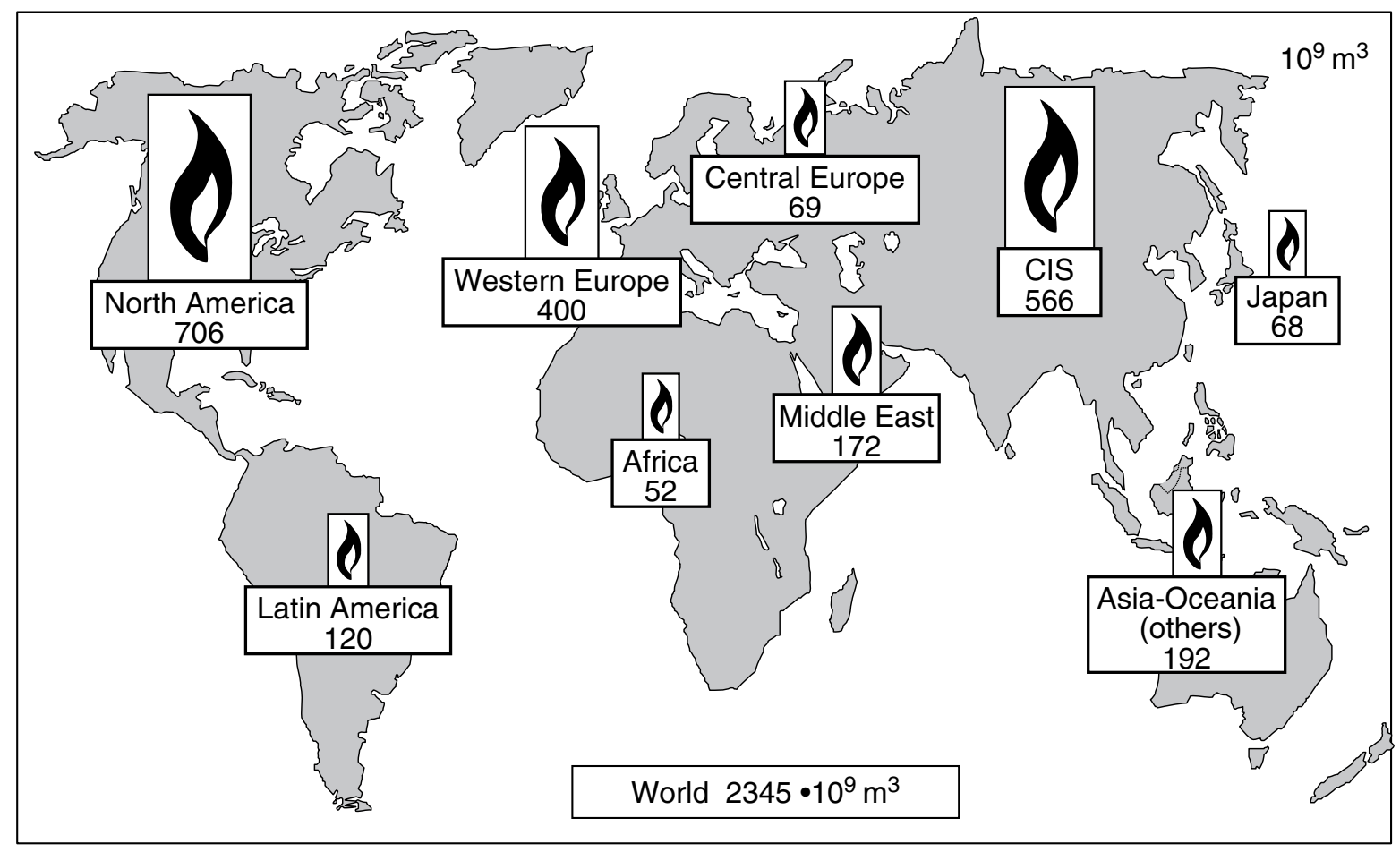

Figure 4

Regional markets of natural gas (1998). 
In the coming years, the global gas expansion will concern all the regions. However, growth rates should be contrasted from one regional market to another. Figure 5 shows the trends.

- Although it is currently undergoing a severe economic crisis, the Asian market is probably offering the best prospects for gas consumption in the long-term. Natural gas is a relatively new source of energy, thus leaving a high growth margin. The Japanese market which already absorbs $26 \%$ of the gas consumed in the region is progressively reaching a maturity phase and only offers limited growth rates. The most significant rise in demand will occur in countries which developed their gas infrastructure more recently: Korea, Taiwan, Malaysia and Thailand. Besides, the Indian Subcontinent and China where energy consumption is increasing rapidly rank among the most promising markets.

- In South America, three countries only have developed their gas industry: Argentina, Mexico and Venezuela. Today, the increase in gas demand is mainly driven by development in Brazil, Chile and Colombia. These countries are gradually building the transport infrastructure necessary to make reserves available to the consuming centers.
- In the Middle East, natural gas share in primary energy consumption is already $40 \%$. In this region, development prospects are linked to the exploitation of vast resources available in Iran, Saudi Arabia and Qatar.

- In Africa, the potential increase in gas demand is concentrated in Algeria, Egypt and a number of countries where large gas reserves are available such as Nigeria.

- Due to the emergence of new consuming countries in Southern Europe, demand for gas in the region will display sustained growth rates in the coming years.

Prospects in more mature regions are more contrasted. Growth in demand should be moderate in the United States. The CIS, where natural gas already has a more than $40 \%$ share of the energy market, is probably the most uncertain region for gas demand outlook. In the short-term, gas demand is likely to stabilize.

While the $O E C D$ countries account for $52 \%$ of total world consumption, they have only $11 \%$ of world reserves. As a result, regional imbalances between production and consuming areas are sharpening, entailing a substantial increase in the international gas trade.

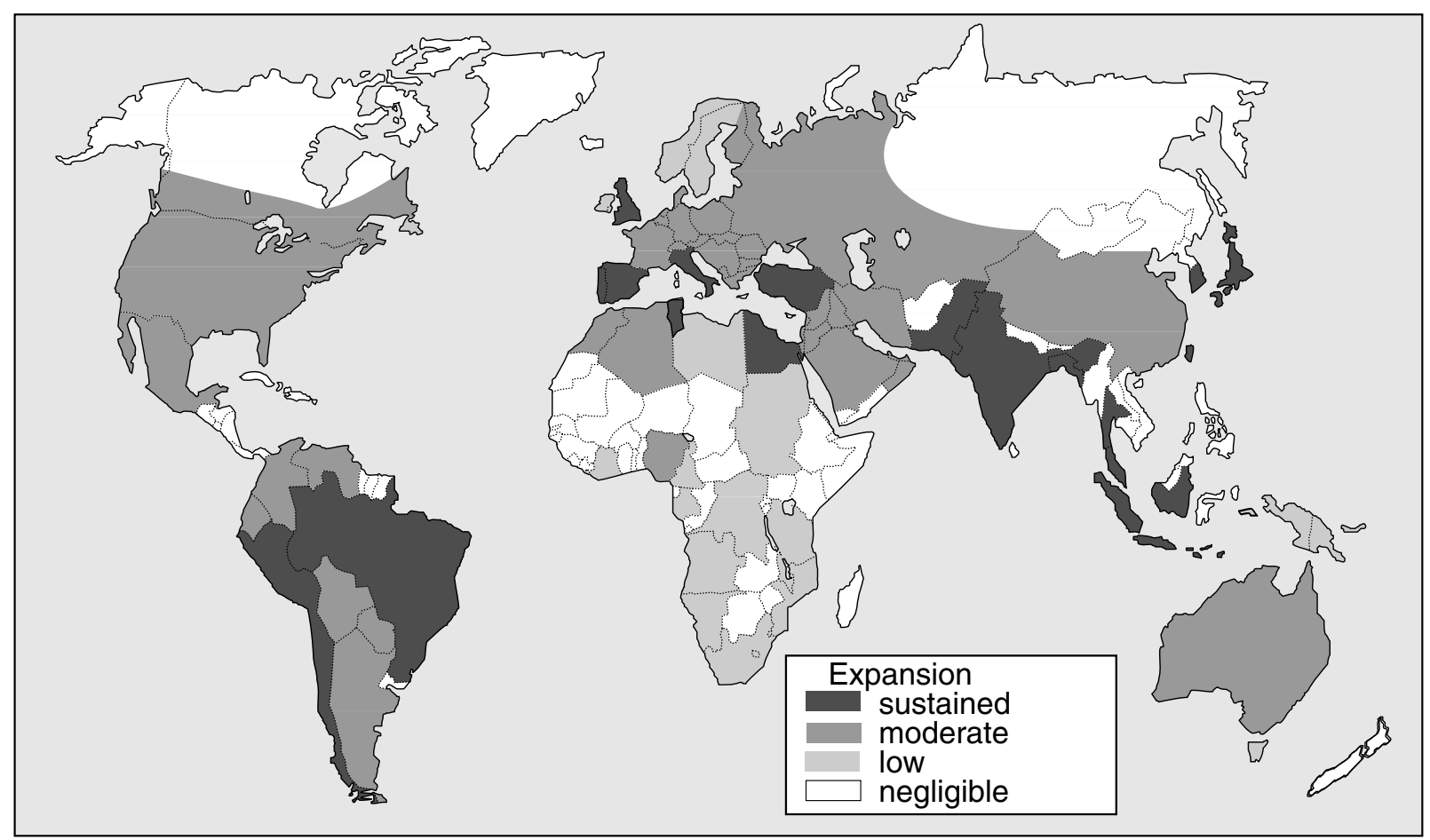

Figure 5

Potential growth of regional gas markets. 


\section{OPPORTUNITIES FOR MIDDLE EAST GAS: ABROAD AND AT HOME}

\subsection{A Huge and Untapped Gas Potential}

The Middle East, ranking second only to the CIS with about $49,400 \cdot 10^{9} \mathrm{~m}^{3}$, holds $32.5 \%$ of world's natural gas reserves. The ratio of proved reserves to production indicates that, at the current production rate of $224 \cdot 10^{9} \mathrm{~m}^{3}$, Mideast reserves could last about 220 years, i.e. almost 4 times the world average of 59 years. Besides, ultimate remaining natural gas resources in the region (including proved gas reserves) are believed to be 120 to $150 \cdot 10^{12} \mathrm{~m}^{3}$.

These figures underscore the level of gas available in the region.

The bulk of Mideast gas reserves is concentrated in about ten supergiant fields (over $1 \cdot 10^{12} \mathrm{~m}^{3}$ ), out of 25 or so on our planet. For instance, the North Dome Field (or North Field), straddling Qatari and Iranian waters, is the world's largest known non-associated gas field, with proved reserves in excess of $10 \cdot 10^{12} \mathrm{~m}^{3}$. On the Iranian side, the extension of the North Field is named South Pars and holds $6.8 \cdot 10^{12} \mathrm{~m}^{3}$ of recoverable reserves. Other supergiant gas accumulations in the region include the North Pars field $\left(1.4 \cdot 10^{12} \mathrm{~m}^{3}\right)$, and Kangan $\left(1.4 \cdot 10^{12} \mathrm{~m}^{3}\right)$ in Iran, as well as Ghawar (about $2 \cdot 10^{12} \mathrm{~m}^{3}$ ) in Saudi Arabia. These major fields are indicated in the Figure 6.

Up to the early 1970s, exploration in the Middle East was primarily aimed at finding oil rather than gas. In the early 1980 s, more specifically gas-targeted exploration led to prolific discoveries, especially in the Khuff formation, with
Qatar, Saudi Arabia, Abu Dhabi, as well as Iran, being the main beneficiaries of upward revisions of gas reserves.

It seems very likely that the potential for the discovery of new large gas accumulations and especially significant volumes of non-associated gas is still high. An upward reassessment of the region proved and ultimate potential is perfectly likely in the coming decades.

\subsection{A Limited Development}

So far, the slow pace of investment has limited the expansion of gas in the Middle East. Although gas represents already an average 35 to $40 \%$ share of the energy balance, the potential is underutilized and there is no similar disparity between large proven reserves and such limited development anywhere in the energy world. The reason is of course that the gas fields which were discovered in the search for oil and - especially in the case of non-associated gas fields - were not seen as economic assets for export purposes due to both technical and cost problems. Also at the time in many cases indigenous outlets were underdeveloped or non-existent.

Over the past decade, marketed production more than doubled mainly as a result of the expansion of the local market. Figure 7 shows that it reached a volume of $170.8 \cdot 10^{9} \mathrm{~m}^{3}$ in 1997 , accounting for only $7.4 \%$ of world production. Although progress still remains to be achieved, the utilization rate of production has been improving steadily and amounts to $67 \%$, compared to the world average of $84 \%$.

The growing use of natural gas mostly results from the recent development of non-associated gas production which has helped the countries to boost their gas output

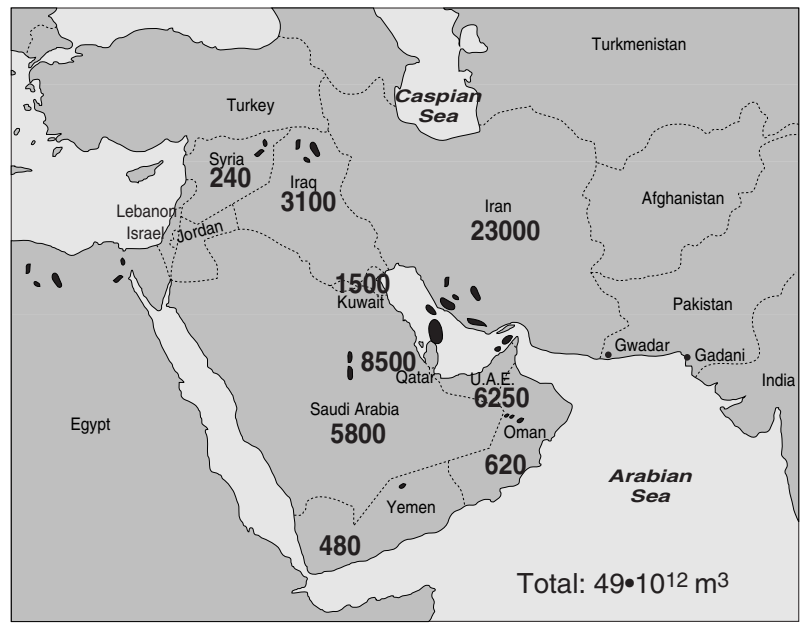

Figure 6

Gas reserves in the Middle East and major fields.

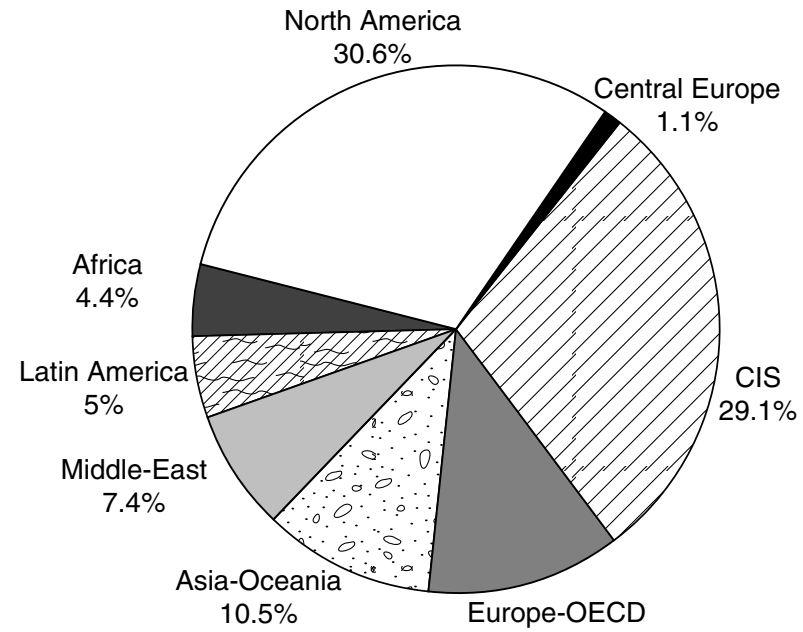

Figure 7

Marketed production of natural gas in the world (1997). 
independently of the amount of oil produced. In addition, a growing concern about the value of gas led to a sharp drop in flaring associated gas. Today, less than $10 \%$ of gas production is being flared.

Besides, gas separation and treatment capacities were built to produce natural gas liquids which are valuable fuels and feedstocks for both local and export markets. For instance, the Master Gas System in Saudi Arabia allowed the recovery and processing of huge amounts of associated gas to produce NGL and LPG. Lastly, most of the Middle East gas countries have implemented reinjection programmes in order to boost oil production or waiting for gas exports schemes to start.

In the future, the Middle East will further expand its production capacities both to meet local requirements and exports. In addition, natural gas is a good strategy for the region's internal market since it will gradually substitute oil products to cover domestic needs, so as to free more oil for increasing export incomes. Gas will also be increasingly needed for reinjection in ageing oil reservoirs to maintain pressure and boost production.

According to Cedigaz' estimates, Middle East marketed gas production might increase to about $320 \cdot 10^{9} \mathrm{~m}^{3}$ by 2010 .

\subsection{Opportunities for Middle East Gas Abroad}

The resource base of the Middle East region vastly exceeds the region's needs and exports represent an appropriate outlet if these reserves are to be utilized. Even though distances between the Middle East and Europe or Asia are long, the region is the nearest large supply source for most of the markets which display the highest demand growth rates.

Technological innovations have had a strong impact in the gas transport sector, in particular now allowing gas trade over very long distances. Contrary to oil, gas is relatively difficult and costly to transport over long distances. Transportation cost for Middle East gas to Europe is about $\$ 1 / \mathrm{MBtu}$ or nearly $\$ 6 / b b l$ compared with about $\$ 1$ for oil, and accounts for $40 \%$ of the price of gas. Cost reduction in this sector represents a crucial factor in securing the expansion of gas trade. Many advances have so far been achieved both for pipeline and tanker transportation, allowing a substantial increase in the international trade. $440 \cdot 10^{9} \mathrm{~m}^{3}$ were traded worldwide in 1997 or $19 \%$ of world marketed production compared to $200 \cdot 10^{9} \mathrm{~m}^{3}$ in 1980 . Technological advances are now progressively setting the stage for new exporting routes. The Middle East, for example, is reinforcing its position on the LNG market aimed at Asian markets more than $11000 \mathrm{~km}$ away. Qatar, Abu Dhabi are also among the major sellers on the LNG spot market with transactions already made with Europe and even the United States. These new gas export routes could only develop thanks to cost reductions made in the past.
Today, the Middle East only accounts for about $4 \%$ $\left(16 \cdot 10^{9} \mathrm{~m}^{3}\right.$ in 1997) of international trade, mainly limited to LNG exports from Abu Dhabi and Qatar to Japan. In the medium-to-long-term, the region should play a crucial role on the international gas market. An export target of about $20 \cdot 10^{9} \mathrm{~m}^{3} / \mathrm{y}$ in 2000 and 60 to $80 \cdot 10^{9} \mathrm{~m}^{3} / \mathrm{y}$ in $2010-2015$ is achievable. Accordingly, the development of export schemes by pipeline and/or LNG tankers is high on the agenda of virtually all Middle Eastern Governments and their foreign partners.

\subsubsection{Existing and Planned LNG Export Infrastructure}

Abu Dhabi and Qatar have already developed their LNG export infrastructures.

- In Abu Dhabi, Das Island liquefaction plant now includes three trains, representing a liquefaction capacity of $7.4 \cdot 10^{9} \mathrm{~m}^{3} / \mathrm{y}$. LNG production is sold to Tokyo Electric Power Company and a few cargoes have been sold to Europe on a spot basis.

- In Qatar, Qatargas, a joint venture among QGPC, Total, Mobil, Mitsui and Marubeni loaded its first $135000 \mathrm{~m}^{3}$ LNG tanker Al-Zubara in December 1996, for the Nagoya terminal in Japan. The company has a commercial purchase agreement to supply $4 \mathrm{Mt} / \mathrm{y}$ to Japan's Chubu Electric over a 25 -year period. A second deal for $2 \mathrm{Mt} / \mathrm{y}$ of additional supply to Japanese buyers was secured in May 1994. Qatar also sells LNG on the spot market to Spain and Turkey. Three trains are operational.

The region is currently implementing five grassroots LNG export projects (Fig. 8). Combined with the already existing LNG plants, Middle Eastern LNG capacity should amount to about $36 \cdot 10^{9} \mathrm{~m}^{3} / \mathrm{y}$ by 2005 .

- Ras Laffan LNG, a partnership between QGPC and Mobil is developing the Rasgas project, initially designed to export around 2.5-5 Mt/y starting in 1999. Ras Laffan LNG already signed an agreement for the sale of $4.8 \mathrm{Mt} / \mathrm{y}$ to Korea Gas Corp. (South Korea). India also signed preliminary agreements to purchase LNG. A letter of intent was signed with Elf Aquitaine to export up to $2 \mathrm{Mt} / \mathrm{y}$ of LNG in Lebanon.

- The second project is Enron LNG Marketing Co's initially planned to export gas to Jordan.

- In the sultanate of Oman, Oman LNG Co., a joint venture among the Government of Oman, Shell, Total, Partex, Mitsubishi, Mitsui and Itochu is building an LNG plant at Al-Ghalilah which is slated to export $6.6 \mathrm{Mt} / \mathrm{y}$ by the turn of the century. Korea Gas Corporation and Osaka Gas from Japan signed purchase agreements.

- Yemen LNG Company, a joint venture between Yemen Gas Company (YGC, 21\%), Total (36\%), Hunt Oil (15.1\%), Exxon (14.5\%), Yukong (8.4\%) and Hyundai Corp. (5\%) is developing a two-train project to export 5.3 to $5.5 \mathrm{Mt} / \mathrm{y}$ of LNG, over a 25 -year period, from a liquefaction facility 


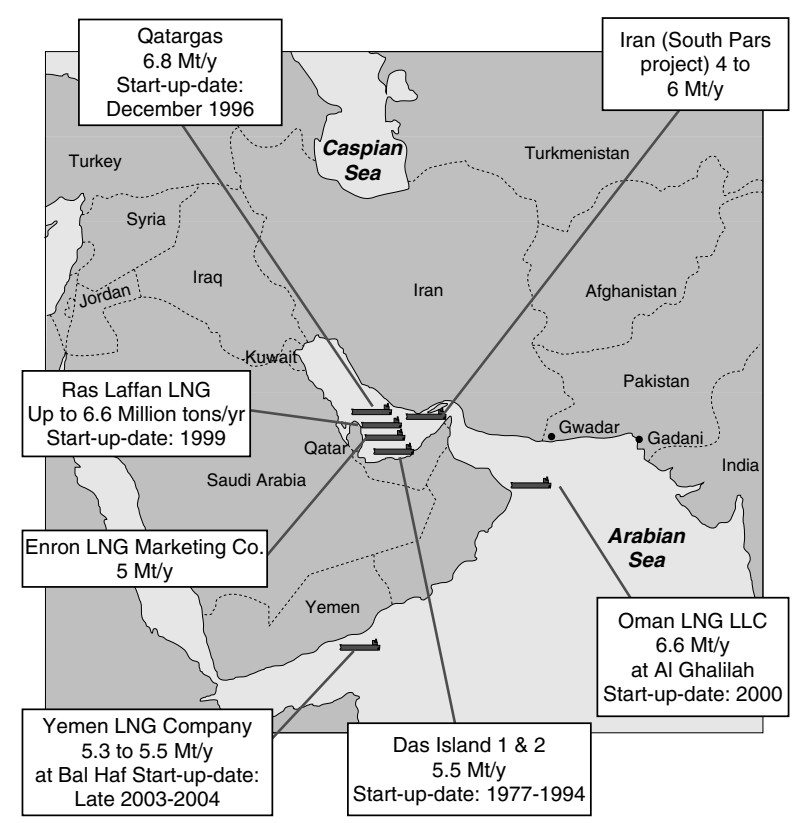

Figure 8

Existing and planned LNG export capacities in the Middle East.

located at Balhaf. As sufficient reserves permit, a third train might later be considered. In January 1997, Yemen authorities and the partners on the $\$ 2.4$ billion project signed seven agreements in particular to incorporate Hunt Oil, Exxon and Yukong.

- Among gas export options, Iran is being studying a 4-6 Mt/y LNG scheme based on the South Pars development with a joint Iranian-European working group, Iran Gas Europe EIG. The Government is also attempting to attract foreign companies to invest in free zones. For instance, a \$8-to 10-billion LNG export venture project could be set up on Qeshm or Kish Islands.

\subsubsection{Pipeline Export Projects}

The European gas market already largely depends on external supplies from Russia, Algeria, Libya and, from 1999, Trinidad and Tobago and Nigeria. Since gas reserves are limited in the region, long-term gas demand growth will entail growing dependence on outside European supplies by the 2007-2010 horizon. Gas from the Middle East is about 4000-5000 km away from the European borders (Fig. 9). Since the 1970's, countries in the Middle East have been studying the possibility of exporting gas by pipeline, targeting Europe. Two major projects can be mentioned.

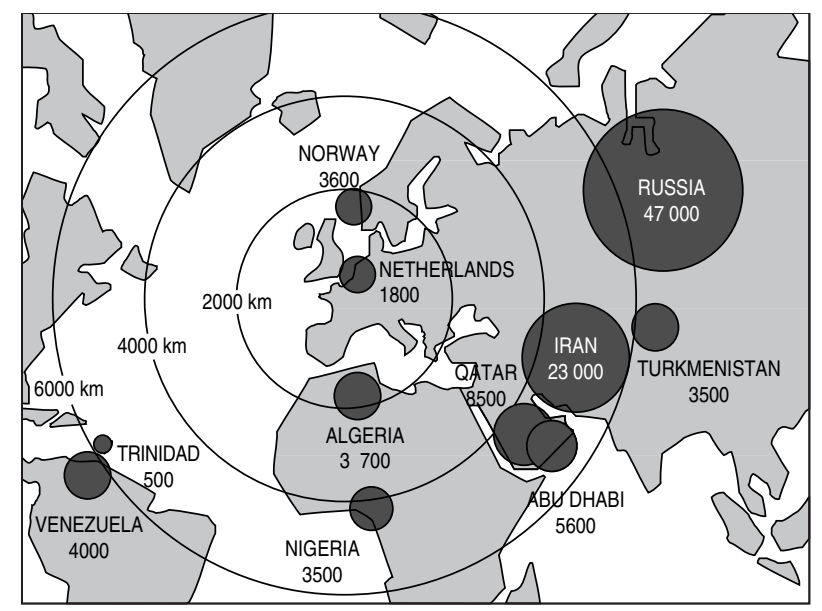

Figure 9

Potential exporters on the European market.

\section{Iran to Europe}

NIGC, and Gaz de France undertook a prefeasibility study to investigate the possibility of exporting Iranian gas to Europe by pipeline. An equally-owned joint venture, Iranian French Gas Cooperation Company Limited, was then established between NIGC and Gaz de France. Another group, called Iran Gas Europe EIG has further been formed among IFGCC Limited and other European companies to further examine the export project. The line would run either via Turkey, south of the Black Sea, or through the Caucasus and Russia to the north of the Black Sea.

\section{Iran to Turkey}

According to the terms of a bilateral agreement, Iran will supply Turkey with $10 \cdot 10^{9} \mathrm{~m}^{3} / \mathrm{y}$ by 2005 . The Iranian section will be about $250 \mathrm{~km}$ from Tabriz to the Turkish border. The section in Turkey will run about $270 \mathrm{~km}$ from the border to Erzerun. In addition, in December 1996, Iran, Turkey and Turkmenistan signed a Memorandum of Understanding covering the transport of natural gas from Turkmenistan to Turkey via existing gas pipelines in Iran. This agreement allows for the transport of $18 \cdot 10^{9} \mathrm{~m}^{3} / \mathrm{y}$, $10 \cdot 10^{9} \mathrm{~m}^{3} / \mathrm{y}$ of which would come from Iran and $8 \cdot 10^{9} \mathrm{~m}^{3} / \mathrm{y}$ from Turkmenistan.

Besides, Iran and Qatar have been studying gas exports to Asia (Pakistan and India). Many other export pipeline projects have also been proposed in the area, in particular to deliver Syrian gas to Turkey, to Lebanon, to Jordan, or to carry Qatari gas to Europe. 


\subsection{Opportunities for Middle East Gas at Home}

The demand for natural gas has developed rapidly during the last ten years growing from $61 \cdot 10^{9} \mathrm{~m}^{3}$ in 1985 to $160 \cdot 10^{9} \mathrm{~m}^{3}$ in 1997 . With $41 \cdot 10^{9} \mathrm{~m}^{3}$, Saudi Arabia, the leading gas consumer in the region, ranks eighth among consuming countries in the world.

The region's natural gas consuming sectors differ basically from those in the rest of the world since energy and power generation sectors take most of the gas, whereas these two sectors account for only about $40 \%$ of worldwide gas consumption. In the future, gas utilization rate will increase further due to a progressive economic policy and emphasis on rapid development and better valorization of gas resources.

Although they will never represent a large potential demand from the reserves available in the gas-rich countries in the region, some local markets where indigenous supplies are restricted may also contribute to the development of gas flows within the Middle East over a longer term.

- Dubai needs gas supplies beyond the year 2000 in particular to feed its growing power generation requirements. Accordingly, the country signed an agreement to import gas from Abu Dhabi. Gas imports from Qatar are also being contemplated.

- Kuwait, which has limited gas reserves and large industrial development plans, could import gas from neighbouring producers in the Gulf.

Intra-regional flows $\left(5.5 \cdot 10^{9} \mathrm{~m}^{3}\right.$ in 1997) currently only concern deliveries from Sharjah and Oman to the Northern Emirates. While intra-zone trade could grow substantially in the future, the setting up of networks is a pre-requisite before any supply can start. So far such projects have proved to be politically difficult.

Several large schemes are being contemplated in the region. These projects are shown on the Figure 10.

- The Gulf Cooperation Council Gas Line, a 5000-mile project from Qatar's North Field to Kuwait, through Bahrain and Saudi Arabia on the one side, and to Dubai and Oman on the other.

- The Gulf-East of the Mediterranean countries network, a network which would enable Qatar and Abu Dhabi to supply countries in the Gulf and east of the Mediterranean.

\section{CHALLENGES AND OPPORTUNITIES FOR THE COMING DECADES}

Today, the industry is experiencing acute turbulences including economic crises in Asia and in Russia and low oil prices to which gas prices are directly linked. This is creating

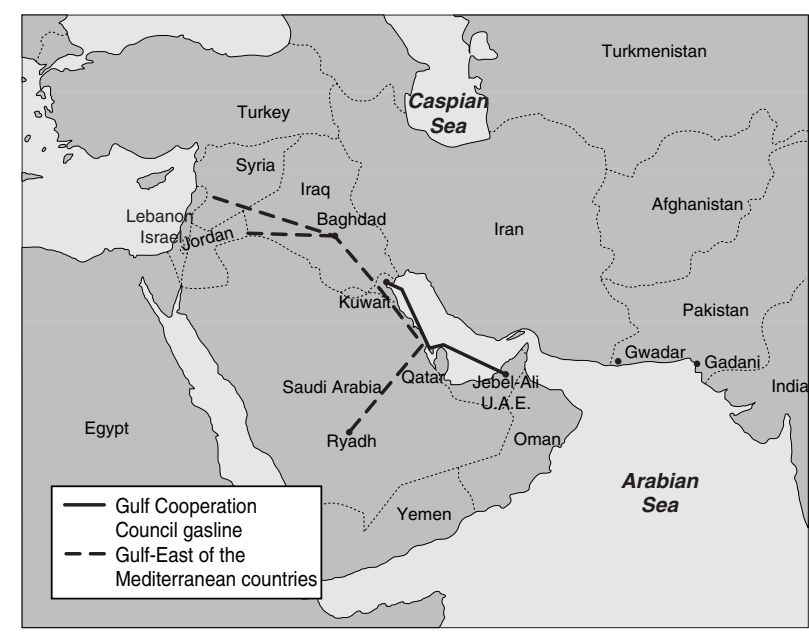

Figure 10

Intra-regional gas pipeline projects.

a climate of uncertainty and hesitation around most of the major gas projects on the drawing board for the beginning of the next century.

\subsection{The Challenge of Prices and Costs}

It is important to compare current, and more importantly future, supply costs with the most representative gas import prices on the main international markets. An LNG export project of $6-8 \cdot 10^{9} \mathrm{~m}^{3} / \mathrm{y}$ requires capital investment of about \$4-5 billion. Similarly, a long-distance gas pipeline with a throughput of $30 \cdot 10^{9} \mathrm{~m}^{3} / \mathrm{y}$ requires an investment of around $\$ 10$ billion. The development costs of most of these grassroots projects are in the $\$ 3-4 / \mathrm{MBtu}$ range, while recent international gas prices establish at $\$ 1.6$ and 2.2/MBtu in North America, about \$2/MBtu in Europe and \$2.7 to 3/MBtu in Japan and the other Pacific Rim importing countries.

With these relative cost and price levels, only a very limited range of projects can be contemplated in the present circumstances. Although there are a number of parameters affecting gas prices that could radically change the situation, the price relationship between oil and gas jeopardizes the economic viability of gas projects, which are capital intensive.

\section{Oil Price Levels}

Natural gas prices on the international markets are very closely tied to the prices of oil and petroleum products and this linkage is unlikely to weaken in the next five to ten years. With current oil prices in the region of $\$ 10 /$ barrel on average, one wonders about future gas prices. 


\subsection{Cooperation for Competitiveness}

Competitiveness will be the determinant factor for the exporting countries' presence in any of the growing markets. The large number of both potential suppliers and export options (LNG and pipeline schemes) existing in the world bring about fierce competition as the targeted markets can be supplied using one or the other transportation mode.

The improvement of gas technologies, in order to reduce the cost of the gas chain and to contribute to the competitiveness of natural gas compared to alternative energy sources constitutes an enormous challenge for the gas industry. All these advances could lead to a substantial reduction in total cost and make available supplies considered too expensive today. Applying the right technology to gas developments can diminish the cost associated to the project and can extend its economic life by many years.

Great progress can still be imagined, developed and implemented, enabling cost reductions of about 25 to $30 \%$ for the overall LNG chain. Cost reductions in pipeline transmission will continue, thanks to research in the field of materials, welding technology and offshore pipe-laying in challenging environments.

\subsection{Opportunities for Future Gas Developments: New Outlets}

In the coming years, new technological advances will undoubtedly help enhance the value of remotly located (Fig. 11) and stranded gas resources (associated with oil, located in deep offshore and in small-size fields). Their development will be of growing importance as we enter the new millenium.

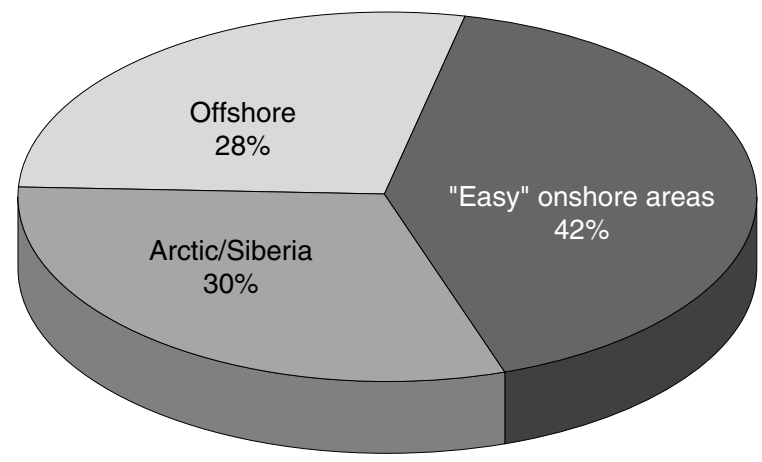

Figure 11

Natural gas reserves: repartition by location.
Today, when no infrastructure for national transmission and distribution is available, there is only a limited number of outlets for the associated gas.

These include gas reinjection (for pressure maintenance or for future recovery) and gas flaring (which is not a preferred option due to resource conservation and greenhouse gas issues). In the most favourable situations, where a transport network and a market are available, the gas is processed and its heavy fractions extracted.

If no pipeline export infrastructure is in place, only remaining options for monetizing gas are limited to liquefaction or GTL conversion. Three main factors favour such projects:

- the will of producing countries to avoid flaring which means that if the gas has to be reinjected its cost is to be considered as negative;

- the need to produce remote gas as well as fields which are smaller than those which are presently considered for LNG projects;

- the large demand for clean fuels. It is clear that whereas the market for chemicals such as methanol or olefins may be rapidly saturated, demand for high quality Diesel fuel appears as almost unlimited. Transportation cost over long distances does not anymore appear as a major handicap in monetizing the resource.

Today, the technology exists and many oil and gas companies are either showing interest or have already implemented R\&D programmes to improve the technology as well as the economics of GTL processes.

\section{CONCLUSION}

Between long-term potential and short to medium-term constraints, it is still difficult to discern the future growth path for natural gas markets, and still more so for natural gas prices. On the one hand there are abundant and growing resources, together with very promising potential demand. On the other, increasingly heavy and expensive infrastructure requirements, and the dubious expectations for gas prices.

New cost reductions in the transportation and distribution sectors will be necessary to cope with the gas-to-gas competition which strengthens gradually and depressed oil prices. R\&D, strategic alliances and diversifications will constitute the three major trends towards success for the companies in the gas sector. 